\title{
OPTIMIZATION OF RANDOM AMPLIFIED POLYMORPHIC DNA TECHNIQUES FOR USE IN GENETIC STUDIES OF CUBAN TRIATOMINAE
}

Jorge FRAGA(1), Jinnay RODRIGUEZ(2), Omar FUENTES(2), Aymé FERNANDEZ-CALIENES(1) \& Mayda CASTEX(2)

\begin{abstract}
SUMMARY
Random amplified polymorphic DNA (RAPD) technique is a simple and reliable method to detect DNA polymorphism. Several factors can affect the amplification profiles, thereby causing false bands and non-reproducibility of assay. In this study, we analyzed the effect of changing the concentration of primer, magnesium chloride, template DNA and Taq DNA polymerase with the objective of determining their optimum concentration for the standardization of RAPD technique for genetic studies of Cuban Triatominae. Reproducible amplification patterns were obtained using $5 \mathrm{pmoL}$ of primer, $2.5 \mathrm{mM}$ of $\mathrm{MgCl}_{2}, 25 \mathrm{ng}$ of template DNA and $2 \mathrm{U}$ of Taq DNA polymerase in $25 \mu \mathrm{L}$ of the reaction. A panel of five random primers was used to evaluate the genetic variability of $T$. flavida. Three of these (OPA-1, OPA-2 and OPA-4) generated reproducible and distinguishable fingerprinting patterns of Triatominae. Numerical analysis of 52 RAPD amplified bands generated for all five primers was carried out with unweighted pair group method analysis (UPGMA). Jaccard's Similarity Coefficient data were used to construct a dendrogram. Two groups could be distinguished by RAPD data and these groups coincided with geographic origin, i.e. the populations captured in areas from east and west of Guanahacabibes, Pinar del Río. T. flavida present low interpopulation variability that could result in greater susceptibility to pesticides in control programs. The RAPD protocol and the selected primers are useful for molecular characterization of Cuban Triatominae.
\end{abstract}

KEYWORDS: RAPD; Triatoma flavida; Triatominae; Optimization; DNA.

\section{INTRODUCTION}

Triatominae play an important role in the transmission of Chagas disease. In Cuba there are four species of Triatominae: Triatoma flavida (Neiva, 1911), Triatoma bruneri (Usinger, 1944), Bolbodera scabrosa (Valdés, 1990) and Triatoma rubrofasciata (De Geer, 1973). T. flavida is considered a sylvatic species that presumably is attracted to houses by light. This species is the most abundant in Cuba, and exhibits characteristics that increase its risk as a potential vector ${ }^{13}$.

The analysis of genetic variations of Triatominae populations using molecular methods constitutes an essential element in taxonomic, biosystematic, epidemiologic, genetic populational and evolution studies $^{4,11}$. Random amplified polymorphic DNA technique (RAPD) constitutes a useful technique for the study of genetic polymorphism of DNA. This involves the amplification of random segments of genomic DNA by Polymerase Chain Reaction (PCR), using short single primers of arbitrary sequence ${ }^{29}$. RAPD requires very small quantities of DNA, and no cloning, sequencing or hybridization are necessary, for this reason, it has a distinct advantage over other molecular techniques generally used for genomic characterization. RAPD technique provided a molecular basis to reassess taxonomic relationships within Triatominae subfamily ${ }^{5,11}$ and epidemiologic studies $^{5}$. Furthermore, it has been used in populational genetic characterization of Rhodnius prolixus and Rhodnius columbiensis ${ }^{12}$, Psammolestes tertius $^{26}$, Triatoma dimidiata ${ }^{7,22}$ and Triatoma braziliensis ${ }^{2,3}$

However, various studies have demonstrated that several experimental parameters can affect the amplification profiles causing false bands and non-reproducibility of assay, ${ }^{1,8,10,21,28}$. Thus, standardization and internal control of this technique is necessary to obtain reproducible profiles by $\mathrm{RAPD}^{8}$. In this report, we describe optimization of the technique through examining the critical parameters, concentration of primer, magnesium chloride, template DNA and Taq DNA polymerase, as required to obtain reproducible results for the characterization of Cuban Triatominae. The genetic polymorphism of six populations of T. flavida was also demonstrated by optimized RAPD.

\section{MATERIAL AND METHODS}

Triatominae: Twelve $T$. flavida adults collected from different localities of Península de Guanahacabibes, Pinar del Río, Cuba (Table 1) were used. 

Cuban Triatominae. Rev. Inst. Med. trop. S. Paulo, 47(5): 295-300, 2005.

Table 1

Data of Triatoma flavida populations studied

\begin{tabular}{|c|c|c|c|}
\hline $\begin{array}{l}\text { Number of } \\
\text { specimens } \\
\text { (origin) }\end{array}$ & Sex & $\begin{array}{c}\text { Collection } \\
\text { site } \\
\text { (Cave) }\end{array}$ & $\begin{array}{c}\text { Area of } \\
\text { Guanahacabibes }\end{array}$ \\
\hline $52(\mathrm{~F} 1)$ & M & Caimanera & East \\
\hline $53(\mathrm{~F} 1)$ & $\mathrm{F}$ & Caimanera & East \\
\hline $54(\mathrm{~F} 1)$ & M & Caimanera & East \\
\hline $55(\mathrm{~F} 1)$ & M & Caimanera & East \\
\hline $56(\mathrm{~F} 1)$ & $\mathrm{F}$ & Caimanera & East \\
\hline $57(\mathrm{~F} 1)$ & $\mathrm{F}$ & Caimanera & East \\
\hline $58(\mathrm{~F} 1)$ & M & Caimanera & East \\
\hline $59(\mathrm{~F} 1)$ & $\mathrm{F}$ & Caimanera & East \\
\hline $60(\mathrm{~F} 1)$ & M & Caimanera & East \\
\hline $61(\mathrm{~F} 1)$ & $\mathrm{F}$ & Caimanera & East \\
\hline 45 (sylvatic) & M & La Barca & East \\
\hline 46 (sylvatic) & $\mathrm{F}$ & La Barca & East \\
\hline 106 (sylvatic) & M & Frances & East \\
\hline 114 (sylvatic) & $\mathrm{F}$ & Frances & East \\
\hline 107 (sylvatic) & M & Helicoptero & East \\
\hline 115 (sylvatic) & $\mathrm{F}$ & Helicoptero & East \\
\hline 34 (sylvatic) & $\mathrm{F}$ & Caimanera & West \\
\hline C (sylvatic) & M & Caimanera & West \\
\hline 108 (sylvatic) & M & Casito & West \\
\hline 109 (sylvatic) & $\mathrm{F}$ & Casito & West \\
\hline 110 (sylvatic) & M & Suerte Amparo & West \\
\hline 48 (sylvatic) & $\mathrm{F}$ & Suerte Amparo & West \\
\hline
\end{tabular}

DNA extraction: Each adult bug was examined individually. A leg was selected as the tissue of choice for the source of genomic DNA using potassium acetate modified method ${ }^{9}$. A single leg was ground to a fine powder with tissue grinders in a $1.5 \mathrm{~mL}$ microcentrifuge tube that contained liquid nitrogen. After grinding, the liquid nitrogen was allowed to evaporate and the powder resuspended in $150 \mu \mathrm{L}$ of lysis buffer (20 mM tris- $\mathrm{HCl}$, pH 8.25, $25 \mathrm{mM}$ EDTA, $25 \mathrm{mM} \mathrm{NaCl}, 1 \%$ SDS). The suspension was incubated with $100 \mu \mathrm{g} / \mathrm{mL}$ of proteinase $\mathrm{K}$ (Boehringer Mannheim, Germany) for one $\mathrm{h}$ at $56{ }^{\circ} \mathrm{C}$. Nucleic acids were extracted with $100 \mu \mathrm{L}$ of potassium acetate $3 \mathrm{M}$, ice incubation for one $\mathrm{h}$ and centrifugation at $8000 \mathrm{Xg}$ for $10 \mathrm{~min}$ at $4{ }^{\circ} \mathrm{C}$. The DNA was precipitated by adding two volumes of absolute ethanol containing $0.3 \mathrm{M}$ sodium acetate and placed at $-20{ }^{\circ} \mathrm{C}$ for 30 minutes. The precipitated genomic DNA was centrifuged at $10000 \mathrm{Xg}$ for $20 \mathrm{~min}$. The DNA pellet was washed in $70 \%$ ethanol. After air drying, the DNA was dissolved in $50 \mu \mathrm{L}$ tris-EDTA buffer (TE) (1 mM tris- $\mathrm{HCl} \mathrm{pH} 8.0$, 1 mM EDTA pH 8.0). The remaining RNA was eliminated with RNaseH (Boehringer Mannheim, Germany) and the suspension was incubated for one $\mathrm{h}$ at $37{ }^{\circ} \mathrm{C}$. After extraction with equal volume of chloroformisoamylic alcohol (24:1), the aqueous phase was conserved at $-20{ }^{\circ} \mathrm{C}$. The DNA concentration was estimated spectrophotometrically by reading absorbance at $260 \mathrm{~nm}$ and the purity of the sample was examined by electrophoresis with a $0.8 \%$ agarose gel in TBE buffer (TBE $0.5 \mathrm{x})(0.045 \mathrm{M}$ tris-borate, $0.001 \mathrm{M}$ EDTA) containing ethidium bromide $(0.5 \mathrm{mg} / \mathrm{mL})$ with visualization using a UV transilluminator (Macrovue 2011, LKB).
RAPD optimization: Three primers were used to optimize the RAPD technique: OPA-1, 2 and 3 (Kit A, Operon Technologies, USA). The amplification was performed in a final volume of $25 \mu \mathrm{L}$ containing $2.5 \mu \mathrm{L}$ of $10 \mathrm{x}$ PCR reaction buffer (Promega, USA) and $200 \mu \mathrm{M}$ of each dNTP (Promega, USA) with different concentrations of primer $(1,2.5,5,7.5$ and 10 pmol per $25 \mu \mathrm{L}), \mathrm{MgCl}_{2}(1.5,2,2.5,3,3.5,4$ $\mathrm{mM})$, template DNA $(5,10,25,50,75,100 \mathrm{ng})$ and Taq DNA polymerase $(0.5,1,1.5,2.0,2.5,3 \mathrm{U}$ per $25 \mu \mathrm{L})$ (Promega, USA), in order to determine their optimal concentrations. Negative controls for each assay contained all components above, except template DNA of T. flavida, in order to discard any contamination. In a thermocycler (Perkin Elmer, USA) the reactions were submitted to the following amplification profile: initial denaturation step at $94{ }^{\circ} \mathrm{C}$ for five min, followed by 45 repetitions of one min at $94{ }^{\circ} \mathrm{C}$, one min at $36{ }^{\circ} \mathrm{C}$ and two min at $72{ }^{\circ} \mathrm{C}$. In the final cycle, the extension step was $15 \mathrm{~min}$. Analysis was done by electrophoresis in $1.2 \%$ agarose gel in TBE buffer containing ethidium bromide $(0.5 \mathrm{mg} / \mathrm{mL})$ with visualization using a UV transilluminator. The presence or absence of each band was scored visually.

The experiments, with optimized conditions, were repeated three times on different days to verify the RAPD reproducibility.

RAPD: The optimized RAPD protocol was used for the amplification of random DNA markers to reveal genetic diversity among T. flavida populations using five oligonucleotide primers (OPA-1 to OPA-5).

Genetic polymorphism analysis: Individual bands were scored as present or absent ( 1 or 0 , respectively) for each specimen and the inverse of Jaccard's similarity coefficient $(\mathrm{Sj}$, as modified by SNEATH, 1957 $)^{25}$ was used, as follows: $\mathrm{Sj}=1-\mathrm{a} /(\mathrm{a}+\mathrm{b}+\mathrm{c})$ where " ${ }^{\circ}$ " represents the number of shared bands, " $b$ " represents the number of bands present in specimen 1 and absent in specimen 2 and "c" represents the number of bands present in specimen 2 and absent in specimen 1.

Phylogenetic relationships were determined by the group-average clustering strategy or the unweighted pair group method with arithmetic averages (UPGMA) ${ }^{24}$ using the SYNTAX 5.0 software package ${ }^{20}$. The dendrogram was constructed based on data from five primers (OPA-1 to OPA-5).

\section{RESULTS}

RAPD optimization: In order to optimize the RAPD technique for T. flavida, several concentrations of primers, $\mathrm{MgCl}_{2}$, template DNA and Taq DNA polymerase were tested, maintaining constant the concentrations of each dNTPs and PCR reaction buffer, using the same amplification profile in the thermocycler. The concentration was selected that produced the highest number and intensity of bands. Figure 1 shows the variations in the amplification product patterns obtained in each case using OPA-2 primer and one specimen of $T$. flavida.

In Figure 1A, by varying the concentration of primer, while maintaining constant concentrations of the other reagents, a relationship between the concentration of primer and the band size is demonstrated. Small fragments (less than $1000 \mathrm{bp}$ ) are generated at high primer concentrations (2.5 to $10 \mathrm{pmol})$, whereas additional large fragments 

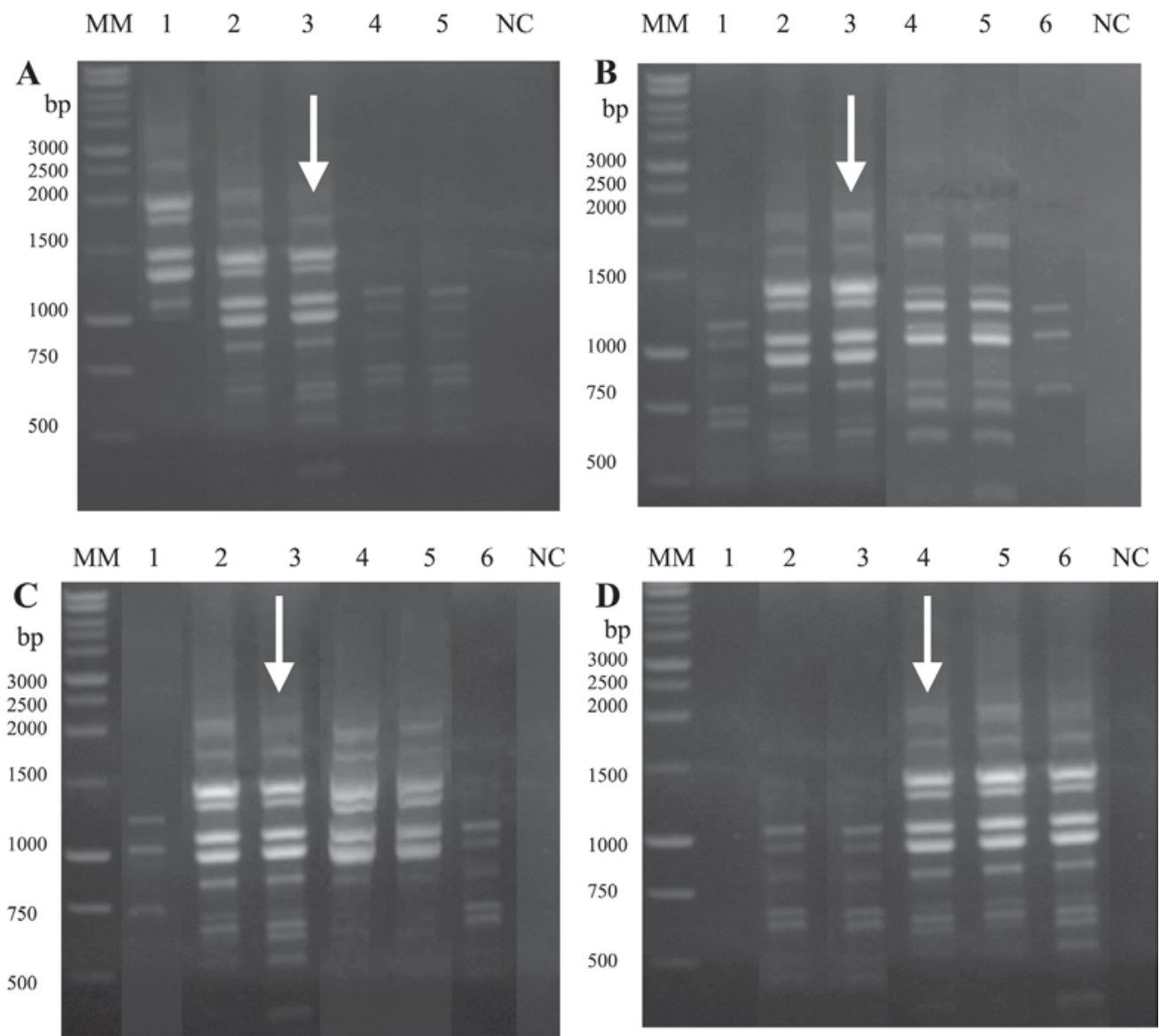

Fig. 1 - RAPD profile of T. flavida (Bug 52) amplified with primer OPA-2. Different concentrations of reagents were tested. (A) primer, $2 \mathrm{U}$ of Taq DNA polymerase, $2.5 \mathrm{mM}$ of $\mathrm{MgCl}_{2}$ and 25 ng of template DNA. Lane 1, 1 pmol ; Lane 2, 2.5 pmol; Lane 3, 5 pmol; Lane 4, 7.5 pmol; Lane 5, 10 pmol (B) magnesium chloride, 2 U of Taq DNA polymerase, 5 pmol of primer and 25 ng of template DNA. Lane 1, $1.5 \mathrm{mM}$; Lane 2, $2 \mathrm{mM}$; Lane 3, $2.5 \mathrm{mM}$; Lane 4, $3 \mathrm{mM}$; Lane 5, $3.5 \mathrm{mM}$; Lane 6, 4 mM. (C) template DNA, 2 U of Taq DNA polymerase, 2.5 mM of MgCl and 5 pmol of primer. Lane 1, $5 \mathrm{ng}$; Lane 2, $10 \mathrm{ng}$; Lane 3, $25 \mathrm{ng}$; Lane 4, $50 \mathrm{ng}$; Lane 5, $75 \mathrm{ng}$; Lane 6, $100 \mathrm{ng}$. (D) Taq DNA polymerase, $25 \mathrm{ng}$ of DNA template, $2.5 \mathrm{mM}$ of MgCl 2 and 5 pmol of primer. Lane 1, 0.5 U; Lane 2, 1.0 U; Lane 3, $1.5 \mathrm{U}$; Lane 4, $2.0 \mathrm{U}$; Lane 5, $2.5 \mathrm{U}$; Lane 6, $3 \mathrm{U}$. The numbers of the left (MM) are the size markers used (Molecular Weight Marker 1kbPromega, USA) and NC negative control without DNA. Arrow represents the optimal condition.

amplify readily at a lower primer concentration $(1$ pmol). Thus, the optimal primer concentration was $5 \mathrm{pmol}$ in $25 \mu \mathrm{L}$ of the reaction.

The variation in $\mathrm{MgCl}_{2}$ concentration modified the RAPD profile (Fig. 1B). The best fingerprinting pattern was obtained using $2.5 \mathrm{mM}$ $\mathrm{MgCl}_{2}$. Lower $(1.5 \mathrm{mM})$ and higher $(3,3.5$ and $4 \mathrm{mM}) \mathrm{MgCl}_{2}$ concentrations had significant effects upon the RAPD profile produced, revealing fewer and non-specific bands.

At a low concentration $(5 \mathrm{ng}$ ) of template DNA only a small amount of product is amplified. This amount increases at $10 \mathrm{ng}$, however $25 \mathrm{ng}$ obtained optimal condition, from there on progressively fewer products appeared with increasing template DNA concentrations (Fig. 1C).

With regard to the Taq DNA polymerase concentration (Fig. 1D), there was a general increase in both the number and intensity of detectable bands with higher Taq DNA polymerase up to $2 \mathrm{U}$, minimal concentration for which the amplification profiles were identical. Thus, the optimal Taq DNA polymerase concentration was $2 \mathrm{U}$.
Regarding the negative controls which contained all of the above components except the template DNA of T. flavida, we did not observe amplification bands, thereby indicating that there was no contamination in the assays.

The same results were obtained when other primers were used (OPA-1 and OPA-3) and other bugs (data not shown).

The reproducibility of banding patterns generated using the standardized RAPD was tested by comparing the fingerprinting generated from triplicate DNA sample extracted from the same Triatominae and amplifications were performed on different days. This was confirmed with ten different $T$. flavida obtained from F1 progeny under laboratory conditions. Figure 2 shows the RAPD patterns of three Triatominae using OPA-2 primer, the identical profile for each one demonstrated high reproducibility of the standardized method. Similar results were obtained upon analyzing other primers (OPA-1 and OPA-3) and other triatominae (data not shown). 


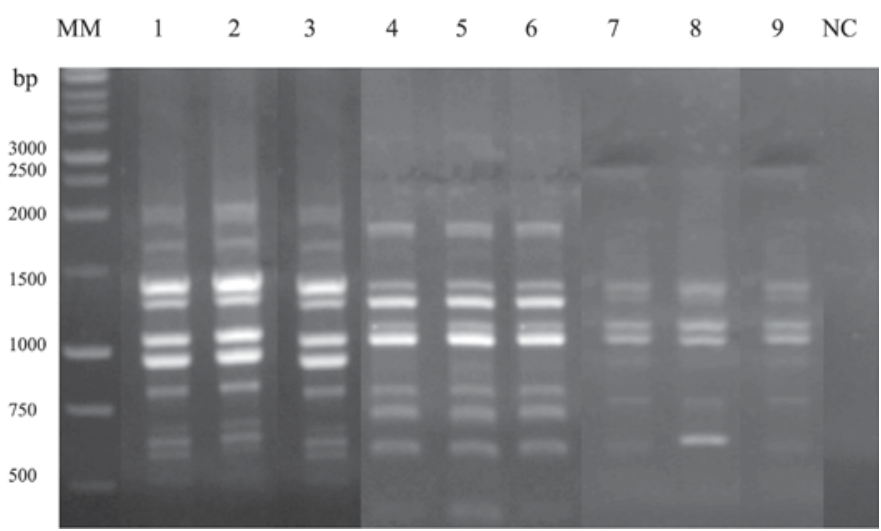

Fig. 2 - RAPD banding patterns obtained from three T. flavida repeated three times on different days using the optimal conditions. Lane MM, Molecular Weight Marker $1 \mathrm{~kb}$ (Promega, USA); Lanes 1-3, bug 52; Lanes 4-6, bug 53; Lanes 7-9, bug 54 and NC negative control without DNA.

Genetic polymorphism between T. flavida populations: Six sylvatic populations of T. flavida, sampled in the western region of Cuba (Guanahacabibes, Pinar del Rio), were analyzed using optimized RAPD technique. Out of the five primers used in this study, only three (OPA-1, OPA-2 and OPA-4) provided reproducible polymorphic patterns of amplified DNA fragments and consequently have the potential to be used in RAPD analysis for specimen differentiation. Figure 3 shows the RAPD profile obtained with one of them (OPA-2). OPA-3 and OPA-5 showed reproducible monomorphic patterns between Triatominae. On average, 10.4 fragments per primer were amplified over all samples. From the 52 reproducible RAPD bands generated in the whole study, 39 bands were totally monomorphic and 13 bands showed variations among specimens.
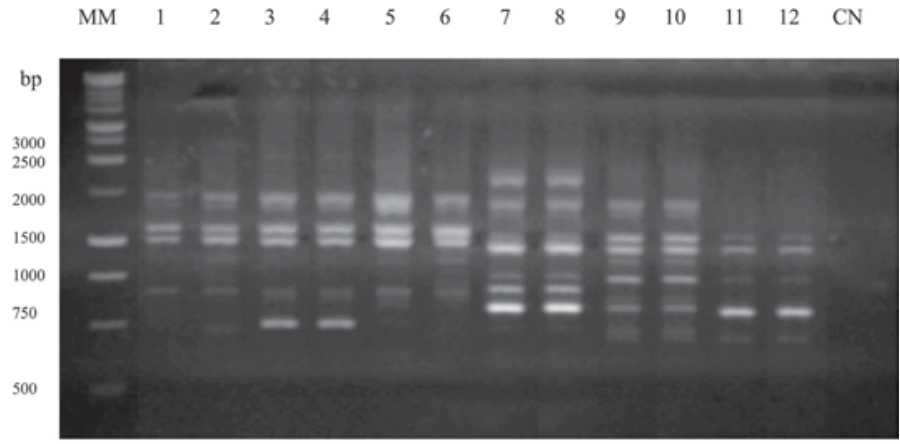

Fig. 3 - RAPD banding patterns obtained from 12 Triatominae using OPA-2 primer. Lane MM, Molecular Weight Marker 1kb (Promega, USA); Lanes 1-12: bugs 45, 46, 106, 114 $107,115,34, \mathrm{C}, 108,109,110,48$ and NC negative control without DNA.

The dendrogram based on calculated Jaccard's distance (Fig. 4) showed two clearly distinguishable clusters: (1) T. flavida collected in Guanahacabibes east of Pinar del Rio; (2) T. flavida collected in Guanahacabibes west of Pinar del Rio. The distance between groups was $\mathrm{Sj}=0.25$, showing a low interpopulation variability.

\section{DISCUSSION}

Molecular biology methods can provide markers with high

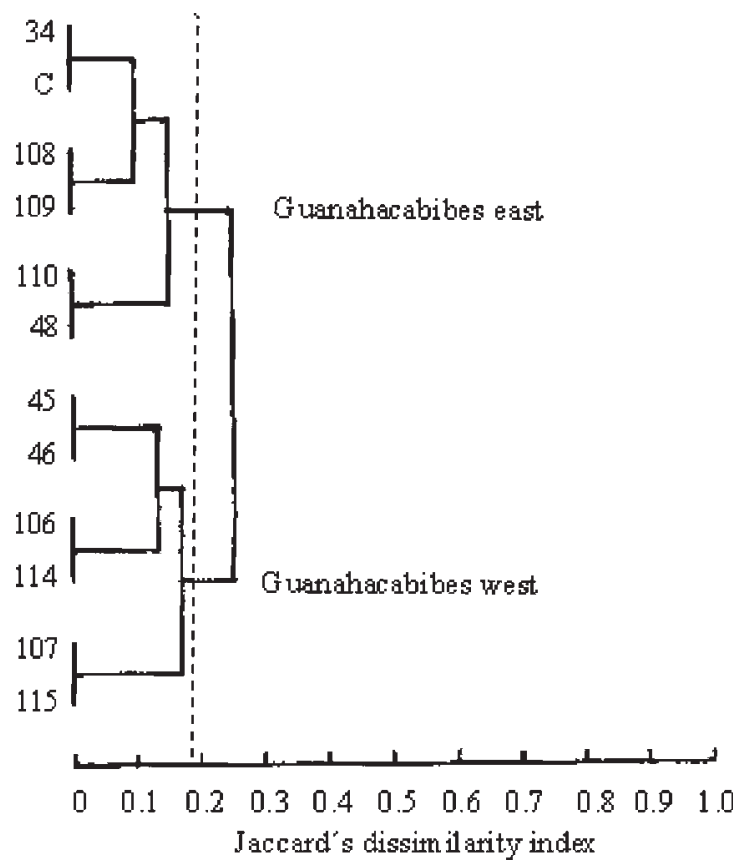

Fig. 4 - Dendrogram generated for specimen populations of T. flavida, using Jaccard's dissimilarity index and the UPGMA algorithm. Dashed line represents the minimum significant distance between any two groups.

discrimination to clarify Triatominae taxonomy and population genetics. The differentiation of intraspecific bug populations has a significant role in the elimination of Chagas disease from the Americas ${ }^{11}$. One relatively straightforward approach is genetic fingerprinting by RAPD ${ }^{11}$.

RAPD may be sufficiently sensitive to access genomic DNA polymorphisms, such as multiple or even single nucleotide insertions and deletions or substitutions. However high level optimization of determining reagents in the amplification reaction, such as the concentration of primer, magnesium chloride, template DNA and Taq DNA polymerase is necessary to obtain reproducible amplification products generated by RAPD. Other factors that affect the reproducibility in the assay considered in this study were the quality of template DNA, annealing temperature and the number of thermal cycles $6,15,17,19$.

When the primer concentration was increased, intensity of large bands decreased, whereas intensity of smaller bands increased. Such differences in the amplification occur because as more primer is available and binds to more locations on the DNA, smaller fragments become more prominent, whereas larger fragments are less conspicuous. This may promote misprinting and accumulation of nonspecific products. On the other hand, when using low concentrations, the primer may be exhausted before the reaction is completed, resulting in lower yields of amplification bands ${ }^{22}$. These variations make it necessary to determine the optimal primer concentration and this is an important element to keep in mind in order to obtain reproducible patterns with a large number of real bands.

PARK \& KOHEL $(1994)^{17}$, evaluated the influence of $\mathrm{MgCl}_{2}$ 
FRAGA, J.; RODRIGUEZ, J.; FUENTES, O.; FERNANDEZ-CALIENES, A. \& CASTEX, M. - Optimization of random amplified polymorphic DNA techniques for use in genetic studies of Cuban Triatominae. Rev. Inst. Med. trop. S. Paulo, 47(5): 295-300, 2005.

concentration on products in PCR to generate RAPD. Varying concentrations of $\mathrm{MgCl}_{2}(1.5$ to $6.0 \mathrm{mM})$ in the PCR mixture resulted in both quantitative differences in RAPD derived DNA and qualitative changes in the DNA patterns. The optimal concentration of $\mathrm{MgCl}_{2}$ was within the range of 1.5 to $2.5 \mathrm{mM}$ in the PCR mixture for 154/ 200 primers tested. After this study, $1.5 \mathrm{mM}$ is considered standard. The optimum $\mathrm{MgCl}_{2}$ concentration in the present study was $2.5 \mathrm{mM}$ since higher or lower concentrations lead to a reduction in the quality of PCR products and the generation of incomplete patterns. Magnesium ion concentration is a critical element in determining the performance of amplification reaction and significantly varied the profiles produced. Low magnesium ion concentration results in poor reaction efficiency, while high concentration results in poor reaction specificity ${ }^{19}$.

The quality and quantity of DNA are factors that also affect RAPD reproducibility. As essentially any primer can amplify very small amounts of DNA from any organism, DNA purity is extremely important in order to obtain clear and discriminatory patterns. In this work a modified potassium acetate method was used, which obtained a high yield and purity DNA with less cost and time, for its use in a RAPD technique ${ }^{9}$. For the majority of organisms, between 10 and 100 ng of highly purified DNA are sufficient to obtain complex and reproducible RAPD patterns ${ }^{6}$. High amounts of DNA usually inhibit amplification due to competition of the primer for the template DNA ${ }^{16}$. Consequently several quantities of DNA should be tested for organisms that have not been fully investigated, not only to ensure a large number of bands, but also in order to verify the conditions for PCR. On analyzing several concentrations of DNA between the above mentioned values, a decrease was observed in the intensity of the bands and a lower number of amplification products starting from $25 \mathrm{ng}$.

Another factor that affects the reproducibility of RAPD pattern is the quantity of Taq DNA polymerase, the intensity of bands increases correspondingly with increasing Taq DNA polymerase up to $2 \mathrm{U}$. After this concentration the amplification profile is not affected by the enzyme concentration. Assay with $2.5 \mathrm{U}$ showed that increased enzyme concentrations lead to decreased specificity ${ }^{27}$. Thus, demonstrating another factor that affects the reproducibility and fidelity of RAPD patterns.

The annealing temperature and number of thermal cycles were other parameters assayed in this study. A $36{ }^{\circ} \mathrm{C}$ annealing temperature was used as this corresponded to the melting point of the analyzed primers ${ }^{14}$. It has been reported that higher temperatures prevent amplification by 10 -mer primers ${ }^{29}$. Relatively low annealing temperatures $\left(34\right.$ to $36{ }^{\circ} \mathrm{C}$ ) are used in RAPD to ensure a maximal number of primer binding events and consequent generation of many amplified DNA fragments ${ }^{1}$. The number of thermal cycles used corresponds to previous studies ${ }^{9,14,23}$, usually at least 40 cycles are necessary to obtain detectable products ${ }^{23}$, while higher numbers of cycles produce an accumulation of nonspecific products ${ }^{27}$.

As the RAPD methodologies achieve broad application in studies of genetic variations in natural populations, artifactual variations, as demonstrated here, may lead to an overestimation of variation level if the artifact is interpreted as a true variation. Our results emphasize important aspects to consider in the experimental design of such studies. The distinction of true polymorphism from artifactual variation is critical, particularly when amplification products are scored as present or absent without regard to the mode of inheritance.

We used the optimal technique for genetic studies of T. flavida collected in the western region of Cuba (Guanahacabibes, Pinar del Rio). In the present study, three primers produced reproducible polymorphism, the usefulness of the primers was evaluated according to two criteria: (1) whether they revealed polymorphisms between different specimens; and (2) whether the polymorphisms were reproducible among samples of the same specimen. As such, they have the potential to be used in RAPD analysis for specimen differentiation.

Our results show low heterogeneity between sylvatic T. flavida populations. The low variability obtained, is an important aspect for the implantation of programs involving insecticide spraying, given the reduced likelihood of resistance to pesticide.

This is the first study to compare populations of T. flavida using genetic tools. RAPD markers help to reveal general tendencies of populations, allowing an understanding of the biology of vectors and hence the development of improved control strategies. Our results confirm that RAPD can be used successfully in Triatominae studies and suggest the presence of genetic variability among different populations of T. flavida.

\section{RESUMEN}

Optimización de la técnica de ADN polimórfico amplificado al azar (RAPD) para su utilización en la caracterización genética de triatomíneos cubanos

La técnica de ADN polimórfico amplificado al azar (RAPD) es un método simple para detectar el polimorfismo genético del ADN. Diferentes factores afectan los perfiles de amplificación lo que se manifiesta en la presencia de bandas falsas y en la reproducibilidad del ensayo. En nuestro trabajo analizamos los cambios de la concentración de cebador, ADN molde, cloruro de magnesio y de Taq ADN polimerasa con el objetivo de determinar su concentración optima, quedando optimizada la técnica del RAPD para su utilización en estudios genéticos de Triatomíneos cubanos. Empleando una concentración de cebador de $5 \mathrm{pmol}, 2.5 \mathrm{mM}$ de $\mathrm{MgCl}_{2}, 25 \mathrm{ng}$ de ADN molde y $2 \mathrm{U}$ de Taq ADN polimerasa en $25 \mu \mathrm{L}$ de reacción, se obtuvieron patrones de amplificación reproducibles. Un total de cinco cebadores al azar fueron usados para evaluar la variabilidad genética de T. flavida. Tres de ellos (OPA-1, OPA-2 y OPA-4) produjeron patrones distinguibles y reproducibles de triatomineos. El análisis numérico según la técnica de UPGMA usando el coeficiente de similitud de Jaccard a partir de las 52 bandas de amplificación de RAPD generadas por los cinco cebadores, fue usado en la construcción del dendograma. Se obtuvieron 2 grupos bien definidos según el análisis del RAPD, mostrando concordancia con el origen geográfico, las poblaciones capturadas en áreas del occidente y el oriente de Guanahacabibes, Pinar del Río, respectivamente. T. flavida presentó una baja variabilidad genética inter-poblacional y esto puede resultar en una mayor susceptibilidad al uso de insecticidas en los programas de control. La técnica de RAPD optimizada y los cebadores seleccionados son útiles para la caracterización molecular de Triatomíneos cubanos. 


\section{ACKNOWLEDGMENTS}

This work was supported in part by grants from European Community Latin American Triatominae Research Network (ECLAT).

\section{REFERENCES}

1. ATIENZAR, F.; EVENDEN, A.; JHA, A.; SAVVA, D. \& DEPLEDGE, M. - Optimized RAPD analysis generates high quality genomic DNA profiles at high annealing temperature. Biotechniques, 28: 52-54, 2000.

2. BORGES, E.C.; DUJARDIN, J.P.; SCHOFIELD, C.J.; ROMANHA, A.J. \& DIOTAIUTI L. - Dynamics between sylvatic, peridomestic and domestic populations of Triatoma brasiliensis (Hemiptera: Reduviidae) in Ceará State, Northeastern Brazil. Acta trop., 93: 119-126, 2005.

3. BORGES, E.C.; DUJARDIN, J.P.; SCHOFIELD, C.J.; ROMANHA, A.J. \& DIOTAIUTI L. - Genetic variability of Triatoma brasiliensis (Hemiptera: Reduviidae) populations. J. med. Entomol., 37: 872-877, 2000.

4. BORGES, E.C.; PIRES, H.H.R.; BARBOSA, S.E. et al. - Genetic variability in Brazilian Triatomines and the risk of domiciliation. Mem. Inst. Oswaldo Cruz, 94 (suppl. 1): 371-373, 1999

5. BRENIÉRE, S.F.; TAVEIRA, B.; BOSSENO, M.F. et al. - Preliminary results of random amplified polymorphic DNA among Triatominae of the phyllosoma complex (Hemiptera, Reduviidae). Mem. Inst. Oswaldo Cruz, 98: 1033-1038, 2003.

6. DIAS-NETO, E.; PEREIRA DE SOUZA, C.; ROLLINSON, D. et al. - The random amplification of polymorphic DNA allows the identification of strains and species of schistosome. Molec. Biochem. Parasit., 57: 83-88, 1993.

7. DORN, P.L.; MELGAR, S.; ROUZIER, V. et al. - The Chagas vector, Triatoma dimidiata (Hemiptera: Reduviidae), is panmictic within and among adjacent villages in Guatemala. J. med. Entomol., 40: 436-440, 2003.

8. ELLSWORTH, D.L.; RITTENHOUSE, K.D. \& HONEYCUTT, R.L. - Artifactual variation in randomly amplified polymorphic DNA banding patterns. Biotechniques, 14: 214-217, 1993

9. FRAGA, J.; RODRÍGUEZ, J.; FUENTES, O.; CAXTES, M. \& FERNÁNDEZCALIENES, A. - Comparación entre cinco métodos para la extracción de ADN de Triatomíneos: su utilización en la técnica de ADN polimórfico amplificado al azar. Rev. cuba. Med. trop., 56: 208-213, 2004

10. FRAGA, J.; ROJAS, L.; SARIEGO, I. \& SARRÍA, C.A. - Optimization of random amplified polymorphic DNA techniques for its use in genetic studies of Trichomonas vaginalis isolates. Infect. Genet. Evol., 2: 73-75, 2002.

11. GARCÍA, A.L.; CARRASCO, H.J.; SCHOFIELD, C.J. et al. - Random amplified polymorphic DNA as a tool for taxonomic studies of Triatomine bugs (Hemiptera: Reduviidae). J. med. Entomol., 35: 38-45, 1998.

12. JARAMILLO, C.; MONTAÑA, M.F.; CASTRO, L.R.; VALLEJO, G.A. \& GUHL, F. Differentiation and genetic analysis of Rhodnius prolixus and Rhodnius colombiensis by rDNA and RAPD amplification. Mem. Inst. Oswaldo Cruz, 96: 1043-1048, 2001.

13. JIMÉNEZ-OZETE, H. - Observaciones sobre la biología de Triatoma flavida, Neiva, 1911 en Cuba. Rev. cuba. Med. trop., 33: 42-50, 1981.
14. KIT MANUAL - Operon Technologies, 2001.

15. MEUNIER, J.R. \& GRIMONT, P.A.D. - Factors affecting reproducibility of random amplified polymorphic DNA fingerprinting. Res. Microbiol., 144: 373-379, 1993.

16. MICHELI, M.R.; BOVA, R.; PASCALE, E. \& D'AMBROSIO, E. - Reproducible DNA fingerprinting with the random amplified polymorphic DNA (RAPD) method. Nucleic Acids Res., 22: 1921-1922, 1994.

17. PARK, Y.H. \& KOHEL, R.J. - Effect of concentration $\mathrm{MgCl}_{2}$ on random amplified DNA polymorphism. Biotechniques, 16: 652-656, 1994.

18. PENNER, G.A.; BUSH, A.; WISE, R. et al. - Reproducibility of random amplified polymorphic DNA (RAPD) analysis among laboratories. PCR Meth. Applic., 2: 341-345, 1993

19. PERSING, D.H. - Target selection and optimization of amplification reaction. In: PERSING, D.H.; SMITH, T.F.; TENOVER, F.C. \& WHITE, T.J., ed. Diagnostic molecular Microbiology: principle and applications. Washington, American Society for Microbiology, 1993. p. 88-103.

20. PONADI, J. - SYN-TAX. Computer programs from multivariate data analysis in ecology and systematics. Version 5.0. Budapest, Scientific Publishing, 1993.

21. QUINTAES, B.R.; LEAL, N.C.; REIS, E.M. \& HOFER, E. - Optimization of randomly amplified polymorphic DNA polymerase chain reaction for molecular typing of Salmonella enterica serovar Typhi. Rev. Soc. bras. Med. trop., 37: 143-147, 2004.

22. RAMÍREZ, C.J.; JARAMILLO, C.A.; DELGADO, M.P. et al. - Genetic structure of sylvatic, peridomestic and domestic populations of Triatoma dimidiata (Hemiptera: Reduviidae) from an endemic zone of Boyaca, Colombia. Acta trop., 93: 23-29, 2005 .

23. SANSINFORIANO, M.E.; RABASCO, A.; MARTÍNEZ-TRANCÓN, M. et al. Optimización de las condiciones RAPD-PCR en Candida spp. y Cryptococcus spp. Rev. iberoamer. Micol., 18: 65-69, 2001

24. SNEATH, P.H.A. \& SOKAL, R.R. - Numerical Taxonomy. San Francisco, W.H. Freeman, 1973.

25. SNEATH, P.H.A. - Some thoughts on bacterial classification. J. gen. Microbiol., 17: 184-200, 1957.

26. SOARES, R.P.P.; BARBOSA, S.E.; BORGES, E.C. et al. - Genetic studies of Psammolestes tertius (Hemiptera: Reduviidae: Triatominae) using male genital morphology, morphometry, isoenzymes and random amplified polymorphic DNA. Biochem. Genet., 39: 1-13, 2001.

27. STEFFEN, C.; ANKENBAUER, W.; POAUER-HOFMANN, R. et al. - PCR applications manual. 2. ed. Mannheim, Roche Diagnostics, 1999

28. WELSH, J. \& McCLELLAND, M. - Fingerprinting genomes using PCR with arbitrary primers. Nucleic Acids Res., 18: 7213-7218, 1990.

29. WILLIAMS, J.G.K.; KUBELIK, A.R.; LIVAK, K.J.; RAFALSKI, J.A. \& TINGEY, S.V. - DNA polymorphisms amplified by arbitrary primers are useful as genetics markers. Nucleic Acids Res., 18: 6531-6535, 1990.

Received: 15 October 2004

Accepted: 29 April 2005 